UDC: 664.8 .037 .1

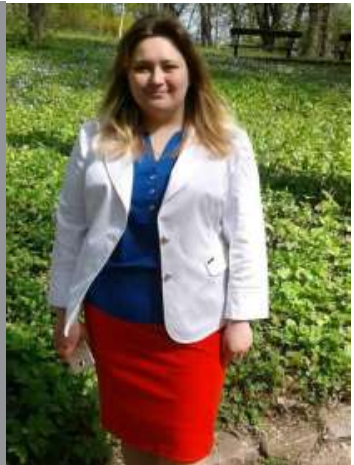

A.H. Blahopoluchna

Postgraduate Student

of Uman National University of Horticulture (Uman), Ukraine.

E-mail: a.blagopoluchna1995@gmail.com

\title{
EFFICIENCY OF PRETREATMENT OF STRAWBERRIES WITH CHITOSAN SOLUTIONS DURING COLD STORAGE IN A MODIFIED GAS ATMOSPHERE
}

Strawberries (Fragaria ananassa) belong to short-term berries. Many technologies are used to extend its shelf life. One of the current technologies is the use of pretreatment of berries with polysaccharide solutions before refrigerated storage. This treatment makes it possible to reduce weight loss and improve the overall quality of berries by forming a protective barrier film on their surface.

The purpose of this study was to investigate the effectiveness of chitosan strawberries pre-treatment while storing it in a refrigerated chamber using a modified gas atmosphere.

To achieve the purpose, strawberries were treated with $0,05 \% ; 0,2 \% ; 0,5 \%$ aqueous solutions of low molecular weight chitosan were stored in a refrigerator at $t 0+2{ }^{\circ} \mathrm{C}$ using polyethylene bags of 30 microns thickness.

Unprocessed berries were used as a control. All experimental studies were performed in triplicate.

According to the research results it was found that the weight loss of treated berries was $1,48-5,11 \%$ and in the control $11,35 \%$. The mass fraction of sugars at the end of storage in the treated berries was $(2,2-2,6 \%)$, which is $0,2-0,6$ times higher than in the control.. The content of ethyl alcohol is fixed in all samples. In the control variant, it was $0,87 \%$, and in the samples the treatment was from 0,57-0,8\% According to the results of the tasting evaluation, the best performance was in the sample with a concentration of $0,5 \%$

Pretreatment of strawberry berries with aqueous solutions of low molecular weight chitosan has a positive effect on the quality of strawberry berries and can be used as an effective tool in the storage of berries.

Key words: strawberries, chitosan, post-harvest processing, modified atmosphere, storage.

А. Г. Благополучна,

аспірантка Уманського національного університету садівництва (м. Умань), Україна

н. О. Ляховська,

викладач Уманського національного університету садівництва (м. Умань), Україна

\section{ЕФЕКТИВНІСТЬ ПОПЕРЕДНЬОГО ОБРОБЛЕННЯ ЯГІД СУНИЦІ РОЗЧИНОМ ХІТОЗАНУ ЗА \\ ХОЛОДИЛЬНОГО ЗБЕРІГАННЯ В МОДИФІКОВАНОМУ ГАЗОВОМУ СЕРЕДОВИЩІ}

Суниця садова (Fragaria ananassa) відноситься до ягідних культур з коротким терміном зберігання. Для подовження терміну ї̈ зберігання використовують безліч технологій. Однією із сучасних технологій є застосування попереднього оброблення ягід розчинами полісахаридів перед холодильним зберіганням. Така обробка дає можливість зменшити втрати маси та покращити загальні показники якості ягід шляхом утворення на їх поверхні плівки, яка виконує роль захисного бар'єру.

Метою даної роботи було дослідити ефективність попереднього оброблення ягід суниці хітозаном під час зберігання ії в холодильній камері з використанням модифікованої газової атмосфери.

Для досягнення мети ягоди суниці обробляли 0,05\%; 0,2 \%; 0,5 \% - ми водними розчинами низькомолекулярного хітозану і зберігали у холодильній камері за t $0 . .2{ }^{\circ} \mathrm{C}$ з використанням поліетиленових пакетів товщиною 30 мікрон. Ягоди без обробки використовували як контроль. Всі експериментальні дослідження виконувались в триразовому повторенні.

За результатами досліджень встановлено, що втрата маси оброблених ягід була на 0,5 - 6,2 \% меншою від контролю. Масова частка цукрів наприкінці зберігання в оброблених ягодах становила (2,2-2,6 \%), що у 0,2-0,6 рази більше за показники в контролі. Вміст етилового спирту зафіксований у всіх зразках. У контрольному варіанті він становив $0,87 \%$, а у зразках обробкою коливався в межах 0,57-0,8\%

За результатами дегустації найкращі показники були у зразку з концентрацією обробки 0,5\%

Попередня обробка ягід суниці водними розчинами низькомолекулярного хітозану має позитивний вплив на якість ягід суниці та може бути застосована як ефективний засіб в технології зберігання ягід.

Ключові слова: суниця, хітозан, післязбиральна обробка, модифіковане середовище, зберігання.

Formulation of the problem. The main task of the food industry is to provide the population with quality products. It is necessary not only to grow raw materials that will meet all requirements, but also to preserve them. It is important to store perishable berry raw materials that have a thin covering fabric and are vulnerable to mechanical damage.

The technology of storage of berry crops is complex and involves the immediate cooling of the collected raw materials, rapid delivery to the storage site and constant maintenance of a certain temperature regime. However, even all these measures do not guarantee complete 
preservation of the goods.

In order to increase the percentage of product output after storage, it is necessary to apply the pre-treatment of berries with solutions of preparations that have film-forming and antibacterial properties.

Analysis of recent research and publications. Strawberry (Fragaria $x$ ananassa) is considered one of the most important fruit in the world, being consumed in natura or in a wide range of processed products [1].

The distribution and commercialization of strawberry in natura at long distances is restrict due to its high perishability, soft texture, high loss of texture and high susceptibility to decay [2].

Postharvest handling practices, such as cold storage, change of storage atmosphere, physical treatments and fruit treatment with edible coatings can reduce the rate of deterioration and maintain product quality after prolonged storage and during marketing [3].

Chitosan is a linear polysaccharide derived from a deacetylated chitin derivative, which is the second most abundant polysaccharide in nature after cellulose. It is non-toxic, biodegradable, bio-functional and biocompatible. Chitosan has a strong antimicrobial and antifungal activity that can effectively control fruit rot [4]. It easily forms coatings on fruits and vegetables and reduces their respiratory rate by regulating the permeability of carbon dioxide and oxygen $[5,6]$.

It has been established that the use of edible films of chitosan can increase the shelf life of strawberries [7, 8].

Recent research suggests that chitosan-based films are capable of reducing weight loss and have a positive effect on the preservation of the antioxidant properties of strawberries [9].

The purpose of the article is to highlight issues regarding the effectiveness of pre-treatment with chitosan solutions to maintain its quality.

Research methodology. Dukat strawberry berries were harvested in nutritional ripeness at the Uman National University of Horticulture. After harvesting, the berries were weighed $500 \mathrm{~g}$ and treated with berries by immersion for $1 \mathrm{~min}$ in aqueous chitosan solutions with concentrations of $0.05,0.2,0.5 \%$. The treated strawberries were left to dry. The dried berries were packed into polyethylene bags (30 microns thick) with a capacity of $500 \mathrm{~g}$. Storage was carried out in a refrigerator at $\mathrm{t}=0+2{ }^{\circ} \mathrm{C}$ and $95 \%$ relative humidity

Analytical studies were performed on the day of harvest before processing and every other day during storage.

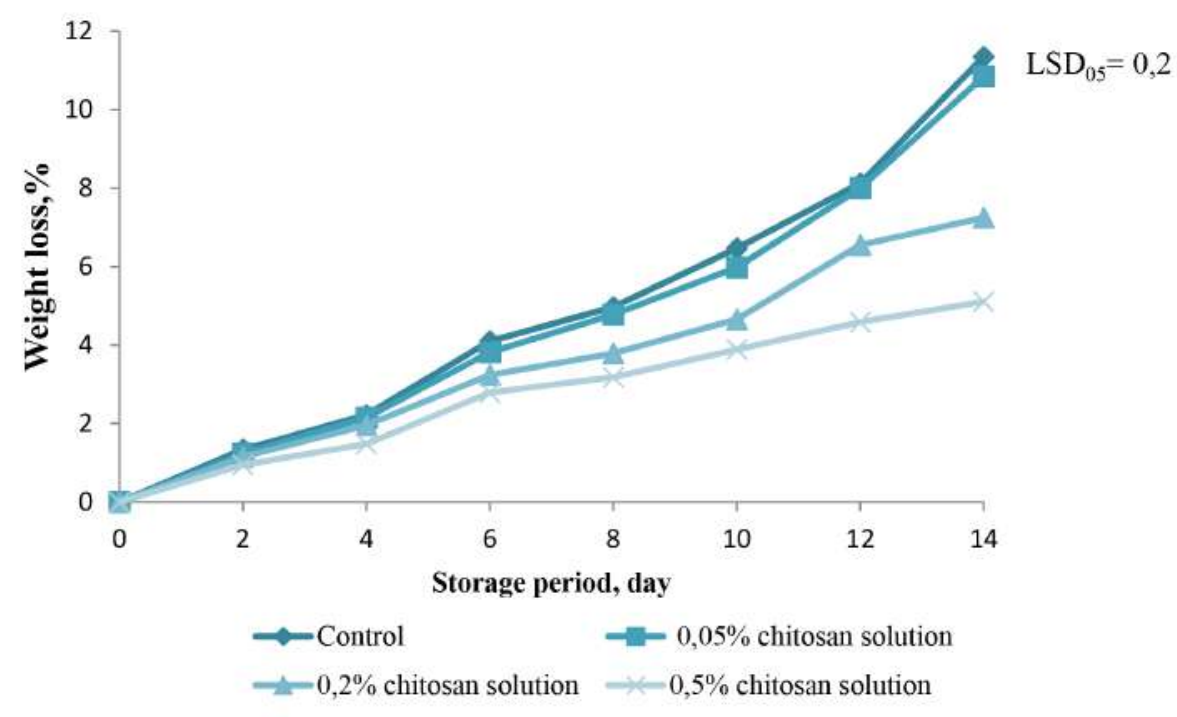

Fig. 1 Weight loss of strawberries during storage

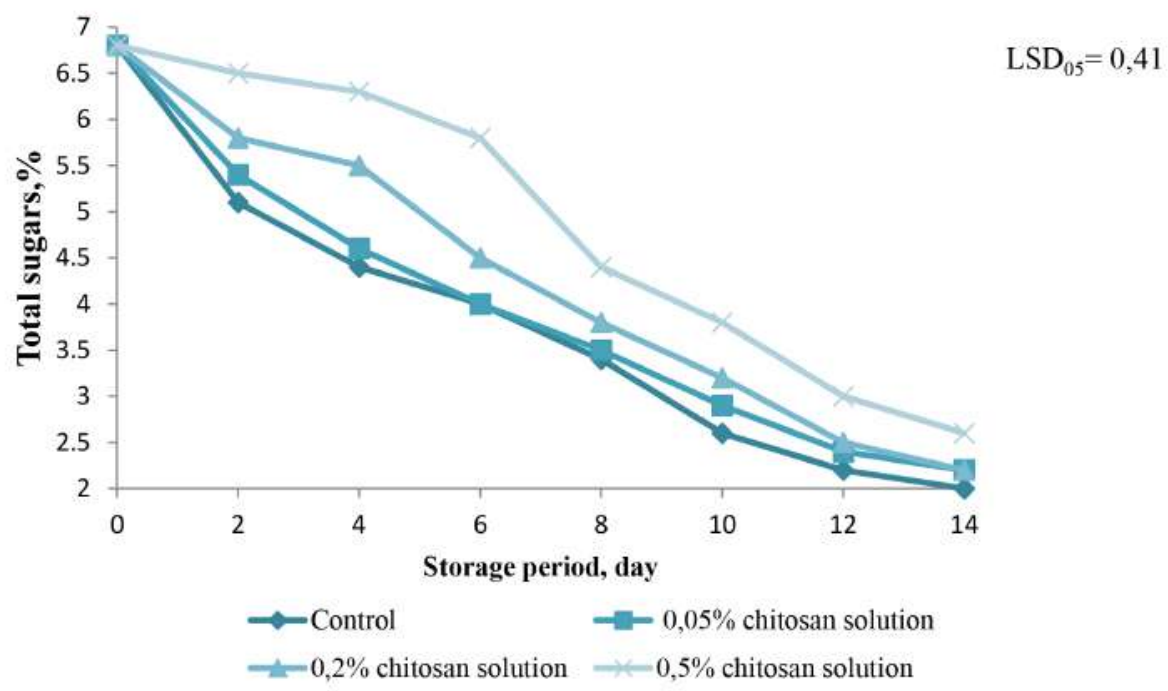

Fig. 2 Total sugars of strawberries during storage 

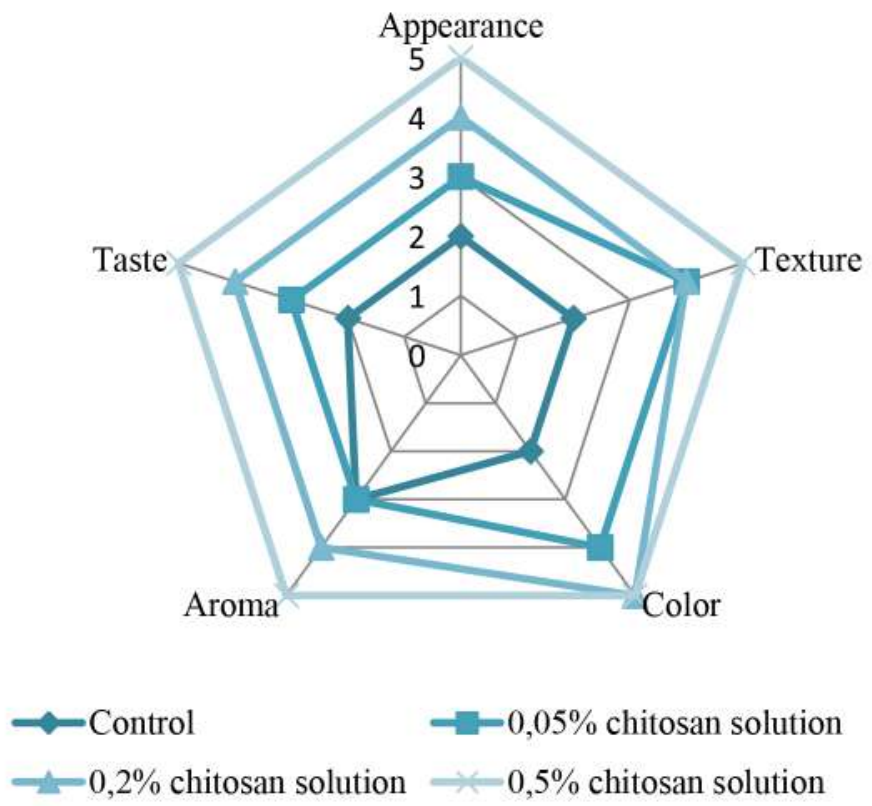

Fig. 3 Organoleptic characteristics of strawberries during storage, point

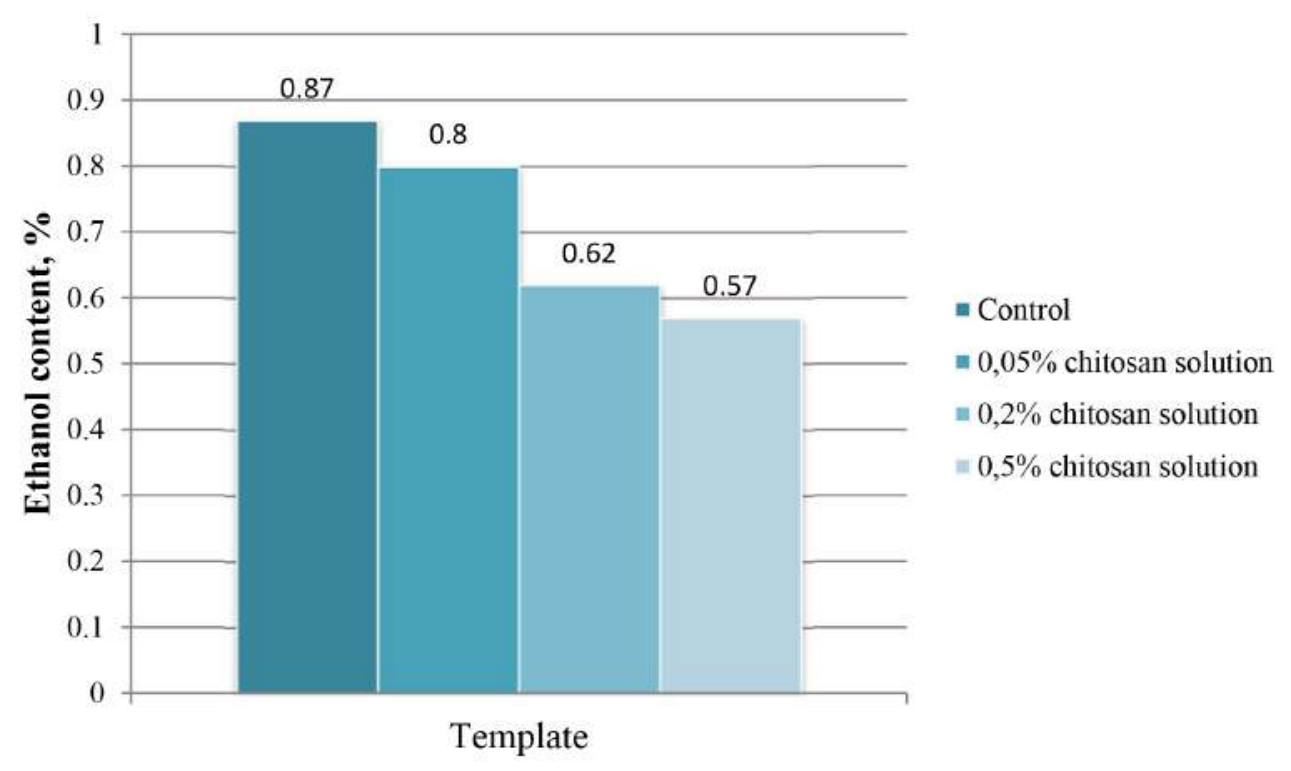

Fig. 4 Ethanol content of strawberries at the end of storage

Weight loss was measured daily.

The main results of the study. It was researched that the average mass of berries of Dukat strawberry in 2019 yield was $6.36 \mathrm{~g}$

The main indicator during storage of berries is the amount of natural weight loss, which should not exceed $6 \%$

It was found that the largest losses were in control, which at the eighth day of storage amounted to $4.9 \%$, which is $0.2-1.8$ times higher than in the treated berries (Fig. 1). At the end of storage, the best result was observed in strawberries treated with a $0.5 \%$ solution of chitosan $5.11 \%$, which is 6.2 times less than in the control.

The main ingredient of the sophisticated taste of strawberries is sugars. Their content depends mainly on the variety and agro-climatic conditions of cultivation. In 2019 strawberries have accumulated $6.8 \%$ of sugars.

During the entire storage period the mass fraction of sugars gradually decreased. Thus, for the eighth day of storage the sugar content of the processed berries was 3.5-4.4 $\%$, which is $0.1-1,0$ times more than in the control. The decrease in sugar content is usually due to the intensity of breathing. At the end of storage, the mass fraction of sugars was $2.2-2.6 \%$ in the treated berries and $2.0 \%$ in the control.

The main indicator of determining the quality of berry products is organoleptic evaluation.

Strawberry berries treated with chitosan solutions had better organoleptic characteristics than controls. Figure 3. According to the results of the tasting evaluation, the option without treatment was the worst. Experts noted that the color of berries is best preserved in variants with a processing concentration of 0.2 and $0.5 \%$. In appearance, taste, aroma and consistency, the sample with the highest concentration of chitosan treatment led the way. 
Ethyl alcohol is a product of anaerobic respiration, which is formed under conditions of high oxygen deficiency in the storage environment.

At the fourteenth day of storage, the content of ethyl alcohol in the treated berries was $0.57-0.80 \%$, which is $0.07-0.20 \%$ than in the control.

Conclusion. It has been established that pretreatment of strawberries with aqueous solutions of low molecular weight chitosan has a positive effect on preserving the quality of berries. It is proved that in the treated berries the mass loss was less by 0.5-6.2 times. The sugar content at the end of storage fluctuated within $2.2-2.6 \%$, which is $0.2-0.6 \%$ more than the control. According to the results of organoleptic evaluation, the sample with the chitosan treatment concentration of $0,5 \%$ is best identified. The highest content of ethyl alcohol was recorded in the control. Pretreatment with chitosan solutions can be used as an effective tool in the storage technology of strawberries.

\section{References}

1. Anami, J. M., Steffens, C. A., Moreira, M. A., Fernandes, R. C., Mosquera, D. J. C., \& Amarante, C. V. T. D. (2020). Active modified atmosphere storage to preserve the quality of'San Andreas' strawberries harvest at two ripening stages. Revista Brasileira de Fruticultura, 42. p. 1

2. Lu, H., Wang, K., Wang, L., Li, D., Yan, J., Ban, Z., ... \& Yang, D. (2018). Effect of superatmospheric oxygen exposure on strawberry
(Fragariax ananassa Fuch.) volatiles, sensory and chemical attributes. (Fragariax ananassa Fuch.) volatiles, sensory and chemical attributes. Postharvest biology and technology, 142. p. 60-71.

3. Siddiqui, M. W. (Ed.). (2017). Preharvest modulation of postharvest fruit and vegetable quality. Academic Press.

4. Aider, M. (2010). Chitosan application for active bio-based films production and potential in the food industry. LWT-food science and technology, 43(6). p. 837-842.

5. Elsabee, M. Z., \& Abdou, E. S. (2013). Chitosan based edible films and coatings: A review. Materials Science and Engineering: $C, 33(4)$ p.1819-1841

6. Jianglian, D., \& Shaoying, Z. (2013). Application of chitosan based coating in fruit and vegetable preservation: A review. J. Food Process. Technol, 4(5). p. 227

7. Valenzuela, C., Tapia, C., López, L., Bunger, A., Escalona, V., \& Abugoch, L. (2015). Effect of edible quinoa protein-chitosan based films on refrigerated strawberry (Fragariax ananassa) quality. Electronic Journal of Biotechnology, 18(6). p. 406-411
8. Pagliarulo, C., Sansone, F., Moccia, S., Russo, G. L., Aquino, R. P., Salvatore, P., ... \& Volpe, M. G. (2016). Preservation of strawberries with an antifungal edible coating using peony extracts in chitosan. Food and bioprocess technology, 9(11). p. 1951-1960.

9. Martínez-González, M. D. C., Bautista-Baños, S., Correa-Pacheco, Z. N., Corona-Rangel, M. L., Ventura-Aguilar, R. I., del Río-García, J. C., \&., Corona-Rangel, M. L., Ventura-Aguilar, R. I., del Río-García, J. C., propolis coatings on the quality and antioxidant capacity of strawberries during storage. Coatings, 10(2). p. 90

\section{Література}

1. Anami, J. M., Steffens, C. A., Moreira, M. A., Fernandes, R. C., Mosquera, D. J. C., \& Amarante, C. V. T. D. (2020). Active modified atmosphere storage to preserve the quality of'San Andreas' strawberries harvest at two ripening stages. Revista Brasileira de Fruticultura, 42. p. 1

2. Lu, H., Wang, K., Wang, L., Li, D., Yan, J., Ban, Z., ... \& Yang, D. (2018). Effect of superatmospheric oxygen exposure on strawberry (Fragariax ananassa Fuch.) volatiles, sensory and chemical attributes. Postharvest biology and technology, 142. p. 60-71.

3. Siddiqui, M. W. (Ed.). (2017). Preharvest modulation of postharvest fruit and vegetable quality. Academic Press.

4. Aider, M. (2010). Chitosan application for active bio-based films production . Aider, M. (2010). Chitosan application for active bio-based films production
and potential in the food industry. LWT-food science and technology, 43(6). and potential in
p. $837-842$.

5. Elsabee, M. Z., \& Abdou, E. S. (2013). Chitosan based edible films and coatings: A review. Materials Science and Engineering: C, 33(4). p.18191841

6. Jianglian, D., \& Shaoying, Z. (2013). Application of chitosan based coating in fruit and vegetable preservation: A review. J. Food Process. Technol, 4(5). p. 227

7. Valenzuela, C., Tapia, C., López, L., Bunger, A., Escalona, V., \& Abugoch, L. (2015). Effect of edible quinoa protein-chitosan based films on refrigerated strawberry (Fragariax ananassa) quality. Electronic Journal of
renten Biotechnology, 18(6). p. 406-411

8. Pagliarulo, C., Sansone, F., Moccia, S., Russo, G. L., Aquino, R. P., Salvatore, P., ... \& Volpe, M. G. (2016). Preservation of strawberries with an antifungal edible coating using peony extracts in chitosan. Food and bioprocess technology, 9(11). p. 1951-1960.

9. Martínez-González, M. D. C., Bautista-Baños, S., Correa-Pacheco, Z. N., Corona-Rangel, M. L., Ventura-Aguilar, R. I., del Río-García, J. C., \& Ramos-García, M. D. L. (2020). Effect of nanostructured chitosan/propolis coatings on the quality and antioxidant capacity of strawberries during storage. Coatings, $10(2)$. p. 90 